\title{
E-BANKING IN RURAL INDIA - WITH SPECIAL REFERENCE TO ERODE DISTRICT, TAMIL NADU.
}

\author{
Dr. Nithya Ramachandran, \\ Faculty - Accounting and Finance Section, \\ Department of Business Studies, \\ Ibra College of Technology, \\ Sultanate of Oman. \\ Email: drlnithya@gmail.com \\ Dr. Abhijieet Sharad kelkar, \\ Associate Professor, Faculty of Management, \\ Symbiosis International University, \\ Pune, India. \\ Email: abhijeetsharadkelkar@gmail.com
}

DOI: $10.31364 / S C I R J / v 6.112 .2018 . P 1218591$

http://dx.doi.org/10.31364/SCIRJ/v6.i12.2018.P1218591

\begin{abstract}
In recent times the Indian population has started availing the facilities of the banks. $E$ banking trend is spreading at a faster rate in all the countries. Banks provide internet banking services to its national and international customers. Internet banking is very cost effective and speedy processing method. The background of the study was to find out whether this advancement of banking technology reach rural areas. The study objectives were framed 1 . To study the impact of demographic factors on the awareness level of respondents about E- Banking. 2. To find and analyze the factors influencing use of E- banking. 3. To find out the opinion of the respondents regarding the various problems of $\mathbf{E}$ banking. The study was conducted collecting information through structured questionnaire from 250 respondents of which $52.8 \%$ of the respondents are male and $47.2 \%$ of the respondents were female. It was found that $55.2 \%$ were holding accounts in public sector banks and $44.8 \%$ of the respondents in private sectors banks. Around $31.2 \%$ of the respondents revealed that they have not used the $E$ banking facility so far. The main reasons for not using the $E$ banking facility being lack of user friendly bank websites and lack of high speed internet. To increase the number of $E$ banking users in rural areas, the banks must provide adequate training to customers, encourage the customers to use the facility and also provide user friendly website.
\end{abstract}

Keywords: E banking, user friendly websites.

\section{INTRODUCTION}

The banking system is the back bone of an economy. The strength of financial system depends on sound banking system. An effective and sound banking system uses its savings in productive sectors and also meets the obligations of the depositors. In the chariot of economic progress, banking is the kingpin. Banking has been emerging at a faster speed recently. Especially with the advent of the support of information technology, the banking has become more easy and faster than it used to be. However, it has the second side of the reality as well. Due to lack of awareness among people, even after decades of emergence of banking industry it was not used effectively. In recent times the Indian population has started availing the facilities of the banks. Late 90's or especially in early 2000's people in India started making use of internet and online services. Banking was not an exception. However, as compared to the other services available on line, use and awareness of the E banking has been with slow pace in 
India. E banking trend is spreading at a faster rate in all the countries. Banks provide internet banking services to its national and international customers. Internet banking is very cost effective and speedy processing method.

The process of using computers/mobiles as a medium for banking services is known as internet banking. The customers access their account information through a web-based service. The bank website permits the customer to log in and do any kind of transactions, but such log in must be authorized by the banking system through personal identification number (PIN). Due to advancement in technology, banks have come forward to accept the change. The banks use electronic and telecommunication networks to provide a huge range of value added services to its customers. Internet plays vital role between banks and customers to receive and deliver information, this form of banking is described as Internet banking (Reserve Bank of India, 2001).

\section{Defining Electronic banking}

A banking system that allows customers to perform bank transactions through internet. Transactions like account transfers, balance enquiries, bill payments, etc. are done through this system. Some banks offer services like loan, credit card applications form through this system. The banking activities can be classified as transactional and non- transactional activities. Electronic transfer of funds, Payment of bills, Loan $\mid \&$ credit card application

Investment products are few of transactional activities and Viewing of account balance,

Viewing of previous transactions, Downloading of Bank statement, Ordering Check book, mobile banking and internet banking application forms are few of non-transactional activities.

\section{RESEARCH SIGNIFICANCE}

The banking industry, being backbone of Indian economy is undergoing vast changes. Advancement in information technology, global business development and demand from customers has paved way for changes in the banking scenario. The study is a bird's eye view of E-banking in rural India. After demonetization, remonetization has taken place. Due to the advancement of technology, banking sector looks ahead for more paperless transactions. This was considered as right time to study about the usage of electronic banking system in rural India. The study aims to understand the awareness about the electronic banking system in rural India. The study was conducted in Modakurachi taluk of Erode district, Tamil Nadu, South India.

\section{STATAEMENT OF THE PROBLEM}

According to census 2011, out of 121 crore Indians, 83.3 crore live in rural areas while 37.7 crore live in urban areas. The total population of Tamil Nadu is 7.21 crores out of which $51.6 \%$ live in rural areas and $48.4 \%$ live in urban areas. (India Population Census, 2011). 


\section{Rural Urban Tamil Nadu}

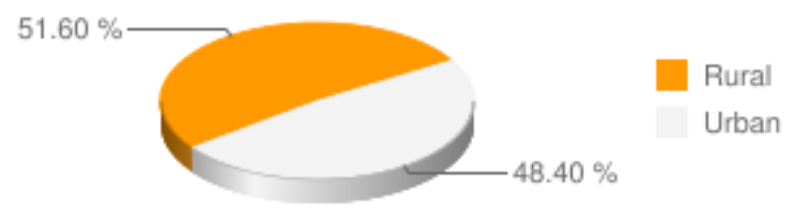

The study area is Erode district, which contributes around 3.12\% of the total population of Tamil Nadu. Around 51.43\% of the Erode district population are staying in urban areas of the district while $48.57 \%$ stay in rural areas.

\section{Rural Urban Erode}

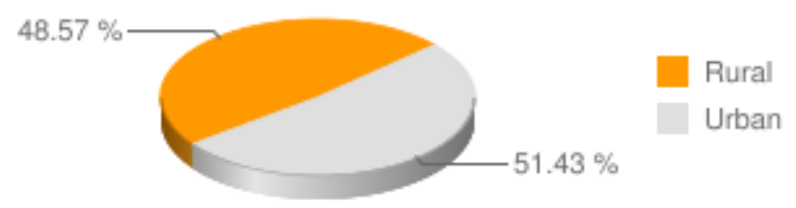

As almost $70 \%$ of the total Indian population lives in rural areas, the significance of the rural area for research scope was found crucial. The study aimed to understand the awareness of electronic banking facilities available to the people in rural areas. This would be an eye opener to the people also to move forward to an electronic transaction mode from paper and manual mode of transactions.

\section{Population outline:}

The study has been conducted in Modakurachi taluk of Erode district. Modakurachi is a town panchayat. The taluk is divided into 15 wards. The population of the taluk with 3076 families is 9907 . The number of male are 4931 and female are 4976 . The sex ratio is 1009 and the literacy rate is $72.4 \%$. (Statistics, 2014-15).

Table 1: Population and literacy data

\begin{tabular}{|l|l|l|l|}
\hline \multicolumn{1}{|c|}{ Data } & \multicolumn{1}{c|}{ Male } & \multicolumn{1}{c|}{ Female } & \multicolumn{1}{c|}{ Total } \\
\hline Population & 4931 & 4976 & 9907 \\
\hline Literacy & $81.25 \%$ & $63.66 \%$ & $72.36 \%$ \\
\hline
\end{tabular}

Data from Census report, 2011

\section{OBJECTIVES OF THE STUDY}

- To study the impact of demographic factors on the awareness level of respondents about E- Banking.

- $\quad$ To find and analyze the factors influencing use of E- banking.

- To find out the opinion of the respondents regarding the various problems of phone / mobile banking.

\section{REASEACRCH METHODOLOGY}

\section{Scope of the study}

This study is a demographical study, based on usage of E-Banking services by various classes of people irrespective of 
occupation, age, sex and literacy. The research work was undertaken by getting the research questionnaires filled by the respondents.

\section{Methodology}

This study is based on primary data collected from the respondents. The data was analyzed with the help of statistical tools like percentage, average, t-test, etc.

\section{Data collection and sampling method}

The primary data was obtained using a well- designed questionnaire. The questionnaire was equipped with questions relating to demographic factors, level of awareness on E- banking among the respondents and factors influencing to choose E- banking. For this study, 250 respondents irrespective of their type of bank account, occupation, age and educational level have been selected randomly as a sample of the data analysis. The major banks available in the study area are Canara bank, Indian overseas bank, State bank of India and City union bank in which the respondents have maintained accounts.

\section{LIMITATIONS OF THE STUDY}

- $\quad$ The study area is confined only to Modakurachi taluk, Erode district, Tamil Nadu.

- The sample size of the research is 250 respondents.

- The data collection was done during the month of July \& August 2018. The attitude of the customer may change in the future.

- The study considers bank transactions done using internet and mobile only as the e banking activities.

\section{ANALYSIS AND INTERPRETATION}

The following tables shows the analysis of data collected with related interpretation detailing the results of the analysis.

Table 2: Gender of the respondents

\begin{tabular}{|c|c|c|}
\hline Gender & No. of Respondents & Percentage (\%) \\
\hline Male & 132 & 52.8 \\
\hline Female & 118 & 47.2 \\
\hline Total & 250 & 100 \\
\hline
\end{tabular}

Source: primary data

The above table shows that $52.8 \%$ of the respondents are male and $47.2 \%$ of the respondents are female.

Table 3: Age of the respondents

\begin{tabular}{|c|c|c|}
\hline Age & No. of Respondents & Percentage (\%) \\
\hline Below 20 Years & 52 & 20.8 \\
\hline 21 to 30 Years & 124 & 49.6 \\
\hline 31 to 40 years & 41 & 16.4 \\
\hline Above 40 Years & 33 & 13.2 \\
\hline Total & 250 & 100 \\
\hline
\end{tabular}

Source: primary data 
The above table clearly states that the maximum percentage of the respondents are in the age group of 21 to 30 years. As the study is related to e-banking, this age group are the maximum users.

Table 4: Educational Qualification of the respondents

\begin{tabular}{|c|c|c|}
\hline Educational Qualification & No. of Respondents & Percentage (\%) \\
\hline Below HSC & 40 & 16 \\
\hline HSC & 38 & 15.2 \\
\hline Under Graduate & 60 & 24 \\
\hline Post Graduate & 62 & 24.8 \\
\hline Professional & 50 & 20 \\
\hline Total & 250 & 100 \\
\hline
\end{tabular}

Source: primary data

From the data collected from the respondents regarding their educational qualification, it shows that higher percentage (24.8 \%) of the respondents are educated upto post graduate level.

Table 5: Occupation of the respondents

\begin{tabular}{|c|c|c|}
\hline Occupation & No. of Respondents & Percentage (\%) \\
\hline Student & 43 & 17.2 \\
\hline Employed & 60 & 24 \\
\hline Self - Employed & 74 & 29.6 \\
\hline House wife & 48 & 19.2 \\
\hline Others & 25 & 10 \\
\hline Total & 250 & 100 \\
\hline
\end{tabular}

Source: primary data

From the above table it clearly shows that $29.6 \%$ of the respondents are self - employed and $24 \%$ of the respondents are employed.

Table 6: Type of bank where account is maintained by the respondents

\begin{tabular}{|c|c|c|}
\hline Type of bank & No. of Respondents & Percentage (\%) \\
\hline Public sector & 138 & 55.2 \\
\hline Private sector & 112 & 44.8 \\
\hline Total & 250 & 100 \\
\hline
\end{tabular}

Source: primary data

The table shows the type of bank where the respondents are maintaining their accounts. Higher percentage $(55.2 \%)$ of the respondents are having their account with the public sector banks and $44.8 \%$ of the respondents are having their account with the private sector banks.

Table 7: Reason for visiting the bank

\begin{tabular}{|l|l|l|}
\hline Reason for visiting bank & No. of Respondents & Percentage $(\%)$ \\
\hline
\end{tabular}




\begin{tabular}{|c|c|c|}
\hline Deposit & 105 & 42 \\
\hline Withdraw & 52 & 20.8 \\
\hline Avail Services & 44 & 17.6 \\
\hline Enquiry & 31 & 12.4 \\
\hline Others & 18 & 7.2 \\
\hline Total & 250 & 100 \\
\hline
\end{tabular}

Source: primary data

The above table points out the reason for visiting the bank by the respondents. Majority (42\%) of the respondents visit the bank for the purpose the depositing their amount in the bank. Around $20.8 \%$ of the respondents are visiting the bank for the purpose of withdrawal.

Table 8: Awareness of E- banking facility

\begin{tabular}{|c|c|c|}
\hline $\begin{array}{l}\text { Awareness of } \\
\text { Banking facility }\end{array}$ & No. of Respondents & Percentage (\%) \\
\hline Yes & 172 & 68.8 \\
\hline No & 78 & 31.2 \\
\hline Total & 250 & 100 \\
\hline
\end{tabular}

Source: primary data

The above table shows that the $68.8 \%$ of the respondents are aware of the E-Banking facility provided by their banks and $31.2 \%$ of the respondents are not aware of the E- Banking facility provided by their bank.

Table 9: Awareness level of E- banking services

\begin{tabular}{|c|c|c|}
\hline $\begin{array}{c}\text { Awareness level of } \\
\text { E-Banking services }\end{array}$ & No. of Respondents & Percentage (\%) \\
\hline Fully aware & 120 & 48 \\
\hline Aware & 52 & 20.8 \\
\hline May be & 30 & 6 \\
\hline Unaware & 15 & 13.2 \\
\hline Totally unaware & 33 & 100 \\
\hline Total & 250 & \\
\hline
\end{tabular}

Source: primary data

Table 9 is the awareness of E-Banking services provided by their bank. The results show that $48 \%$ of the respondents are fully aware of the services provided by their respected banks. Around $20.8 \%$ of the respondents are aware of the E-Banking services. The study reveals that around $13.2 \%$ of the respondents are totally unaware of the E-Banking services.

Table 10: Reasons for lack of awareness

\begin{tabular}{|c|c|c|}
\hline $\begin{array}{c}\text { Reasons for lack } \\
\text { of awareness }\end{array}$ & No. of Respondents & Percentage (\%) \\
\hline Education & 78 & 31.2 \\
\hline Lack of facility & 85 & 34 \\
\hline
\end{tabular}




\begin{tabular}{|l|c|c|}
\hline $\begin{array}{l}\text { Account not self- } \\
\text { maintained }\end{array}$ & 87 & 34.8 \\
\hline Total & 250 & 100 \\
\hline
\end{tabular}

Source: primary data

The above table shows the reasons for the lack of awareness on E-Banking among the respondents. The reason with higher percentage (34.8) is that the account is not self- maintained.

Table 11: Reason for using the E-Banking facility

\begin{tabular}{|c|c|c|}
\hline $\begin{array}{c}\text { Reasons for using E- } \\
\text { Banking facility }\end{array}$ & No. of Respondents & Percentage (\%) \\
\hline Easy & 75 & 30 \\
\hline Safe and secure & 52 & 20.8 \\
\hline Low transaction charges & 45 & 18 \\
\hline Not used & 78 & 31.2 \\
\hline Total & 250 & 100 \\
\hline
\end{tabular}

Source: primary data

Table 11 states the reasons for using the E- Banking facility by the respondents. $31.2 \%$ of the respondents have not used the facility and $30 \%$ of the respondents used the facility as it is easy and $18 \%$ of the respondents are using the facility because of low transaction charges.

Table 12: Usage of E-Banking facility based on familiarity

\begin{tabular}{|c|c|c|c|c|c|c|}
\hline $\begin{array}{c}\text { Usage of e- } \\
\text { banking facility } \\
\text { based on } \\
\text { familiarity }\end{array}$ & $\begin{array}{l}\text { Strongly } \\
\text { familiar }\end{array}$ & Familiar & Neutral & $\begin{array}{c}\text { Very less } \\
\text { familiarity }\end{array}$ & $\begin{array}{l}\text { Completely } \\
\text { not familiar }\end{array}$ & Total \\
\hline Internet browsing & 120 & 52 & 30 & 40 & 8 & 250 \\
\hline $\begin{array}{l}\text { visiting bank } \\
\text { website }\end{array}$ & 112 & 46 & 29 & 35 & 28 & 250 \\
\hline $\begin{array}{l}\text { Access of online } \\
\text { banking information }\end{array}$ & 108 & 44 & 25 & 42 & 31 & 250 \\
\hline $\begin{array}{l}\text { Viewing account } \\
\text { statements }\end{array}$ & 115 & 50 & 30 & 25 & 30 & 250 \\
\hline Transfer funds & 110 & 41 & 22 & 28 & 49 & 250 \\
\hline Make bill payments & 115 & 52 & 26 & 27 & 30 & 250 \\
\hline $\begin{array}{l}\text { Avail banking } \\
\text { facilities online }\end{array}$ & 100 & 48 & 22 & 35 & 45 & 250 \\
\hline
\end{tabular}

Source: primary data

The above table shows the usage of E-Banking facility based on the familiarity of the facility. Majority of the respondents (120 respondents) are familiar with internet browsing which is makes them familiar with the E-Banking facility. 
Table 13: Reasons for not using E-Banking facility

\begin{tabular}{|c|c|c|c|c|c|c|}
\hline \multirow{2}{*}{$\begin{array}{l}\text { Reasons for not using e- } \\
\text { banking facility }\end{array}$} & \multicolumn{5}{|c|}{ Rank } & \multirow{2}{*}{ Total } \\
\hline & 1 & 2 & 3 & 4 & 5 & \\
\hline $\begin{array}{l}\text { Lack of enough } \\
\text { knowledge }\end{array}$ & 49 & 60 & 72 & 25 & 44 & 250 \\
\hline No computer & 20 & 32 & 35 & 43 & 120 & 250 \\
\hline $\begin{array}{l}\text { Lack of high speed } \\
\text { internet }\end{array}$ & 95 & 74 & 49 & 22 & 10 & 250 \\
\hline $\begin{array}{l}\text { Non-user friendly bank } \\
\text { website }\end{array}$ & 64 & 44 & 40 & 72 & 30 & 250 \\
\hline $\begin{array}{l}\text { No regular banking } \\
\text { activities }\end{array}$ & 22 & 40 & 54 & 88 & 46 & 250 \\
\hline Total & 250 & 250 & 250 & 250 & 250 & \\
\hline
\end{tabular}

Source: primary data

The above table shows that the reasons for not using E-Banking facility. Around 95 respondents say that lack of high speed internet facility is the reason for not using the facility.

Even though in the beginning as well as during the research especially while collecting the data, the hypotheses were not made.

However, after the data are collected and analyzed, the researcher observed the observations to be independent of each other even though the grouping of the questions relating to each other are collectively compared with weighted averages.

The distribution of the factors responsible for the usage of the internet facility and not using the E banking facility was done, the sample size is taken for those factors only and not the respondents.

Hence, in order to test the mean difference between the two independent approaches registered by the respondents through their responses, the hypothesis was set by the researcher. The main purpose of the research is to measure the statistical difference between the two approaches of usage and non-usage of the e banking facility of the banking emerged through collected data.

Null Hypothesis: There is no effect of the interdependency of the factors relating to the usage of the banking facility by the customers.

Alternate Hypothesis: There is an effect of the interdependency of the factors to the usage of the banking facility of the customers.

Table 14: Weighted average on usage of E- Banking facility based on familiarity.

\begin{tabular}{|l|c|c|c|c|c|c|c|}
\hline $\begin{array}{c}\text { Usage of E- Banking } \\
\text { facility based on } \\
\text { familiarity }\end{array}$ & $\begin{array}{c}\text { Strongly } \\
\text { familiar }\end{array}$ & Familiar & Neutral & $\begin{array}{c}\text { Very less } \\
\text { familiarity }\end{array}$ & $\begin{array}{c}\text { Completely } \\
\text { not familiar }\end{array}$ & Total & W.Avg. \\
\hline Internet browsing & 120 & 52 & 30 & 40 & 8 & 250 & 3.944 \\
\hline visiting bank website & 112 & 46 & 29 & 35 & 28 & 250 & 3.716 \\
\hline $\begin{array}{l}\text { Access of online } \\
\text { banking information }\end{array}$ & 108 & 44 & 25 & 42 & 31 & 250 & 3.624 \\
\hline $\begin{array}{l}\text { Viewing account } \\
\text { statements }\end{array}$ & 115 & 50 & 30 & 25 & 30 & 250 & 3.78 \\
\hline Transfer funds & 110 & 41 & 22 & 28 & 49 & 250 & 3.54 \\
\hline Make bill payments & 115 & 52 & 26 & 27 & 30 & 250 & 3.78 \\
\hline $\begin{array}{l}\text { Avail banking } \\
\text { facilities online }\end{array}$ & 100 & 48 & 22 & 35 & 45 & 250 & 3.492 \\
\hline
\end{tabular}


Source:

primary data

\begin{tabular}{|c|c|c|c|}
\hline Mean & SD & SD Square & N 1 \\
\hline 3.696571 & 0.144988 & 0.021022 & 7 \\
\hline
\end{tabular}

Table 15: Reasons for not using E-Banking facility.

\begin{tabular}{|c|c|c|c|c|c|c|c|}
\hline \multirow{2}{*}{ Reasons for not using E-Banking facility } & \multicolumn{5}{|c|}{ Rank } & \multirow{2}{*}{ Total } & \multirow{2}{*}{ W.Avg. } \\
\hline & 1 & 2 & 3 & 4 & 5 & & \\
\hline Lack of enough knowledge & 49 & 60 & 72 & 25 & 44 & 250 & 2.82 \\
\hline No computer & 20 & 32 & 35 & 43 & 120 & 250 & 3.844 \\
\hline Lack of high speed internet & 95 & 74 & 49 & 22 & 10 & 250 & 2.112 \\
\hline Non-user friendly bank website & 64 & 44 & 40 & 72 & 30 & 250 & 2.84 \\
\hline No regular banking activities & 22 & 40 & 54 & 88 & 46 & 250 & 3.384 \\
\hline Total & 250 & 250 & 250 & 250 & 250 & - & - \\
\hline
\end{tabular}

Source: primary data

\begin{tabular}{|c|c|c|c|}
\hline Mean & SD & SD Square & N 2 \\
\hline 3 & 0.584181 & 0.341267 & 5 \\
\hline
\end{tabular}

\begin{tabular}{|l|}
\hline Standard Error of Diff $\mathbf{= 0 . 2 6 6 9 3 9}$ \\
\hline Mean $1-$ Mean 2 / Standard Error of Difference \\
\hline $0.696571 / 0.266939$ \\
\hline t value $=\mathbf{2 . 6 0 9 4 7 8}$ \\
\hline
\end{tabular}

As the calculated t value is more than the $\mathrm{t}$ value as per the table, Null Hypothesis is rejected.

\section{CONCLUSION:}

The following conclusions were drawn from the study:

- Inter dependency of the factors affecting the usage of banking facility and non-usage of the banking facility is a major factor while measuring the banking facility used by the customers.

- Out of the respondents, the non-usage of the e banking due to non-availability of the computers and usage of the e banking facility based on familiarity, the weighted averages are maximum. In the sense, the respondents in both the categories remain to be the same and their responses carry inter dependency.

- Not user friendly bank web facility and lack of knowledge remain to be the qualitative aspects. For want of their clearly defined criteria norms, the responses trend is skewed towards non-usage of the e banking facility.

- As the neutral category responses registered also constitute a considerable portion of the registered responses, the clarity and expectations of the respondents in terms of the usage and non-usage of the e banking services is affected.

\section{RECOMMENDATIONS:}

The following recommendations are cited based on the study results:

- Banks should educate the customers in two tiers. Making of website user friendly and ensuring increased usage of the e banking by the customers. 
- Banks should focus more in rural areas as, the lack of knowledge of in general use of internet and e banking facilities hinder the development and usage of banking services.

- Banks should also ensure the compatibility of the IT services with the network service providers.

\section{Bibliography}

2011, C. (2011). District wise census, 2011.

(2011). India Population Census.

Statistics, D. D. (2014-15). District statstical handbook. 